migration of cobalt-60 and whatever the difference in rate between killed versus living inoculum or $P$. filamentosa as compared with $R$. stolonifer, the percentage of cobalt- 60 and the distance over which it is transported are very small indeed. In every case most of the activity is retained in the section of the soil containing the inoculum. There the nuclide may be held by either adsorption on the soil colloids after having diffused through the cell wall of the fungi or within the hyphæ of the original inoculum, possibly bound to the protoplasm.

Regarding the first point, this would fit in with the observation of Jones et al. ${ }^{15}$, who have shown that in a soil with moderate exchange capacity cobalt-60 remains close to the surface even after repeated applications of water. These workers placed the cobalt- 60 directly in the soil, while in the experiments described here it was introduced via the fungal inoculum; the soil used was one of moderate exchange capacity.

On the second possibility, Harley and MeCready 5 have shown that in the case of excised mycorrhizal roots of the beech 90 per cent of phosphorus-32 absorbed from aerated media was found to be held in the fungal sheath and only 10 per cent diffused into the core. This ratio varied with environmental conditions'. By analogy it could be assumed that cobalt-60 also is firmly held within the fungal tissue, especially in view of the observations that migration is of lower order from the living than from the dead inoculum. Thus, the possibility is not ruled out that the small migration which had occurred from living inocula was due to some extent to active transport inside the fungal tissue, perhaps by protoplasmic flow. This is a hypothesis, and more work is required to distinguish between migration by diffusion or by active translocation. Probably both factors will operate simultaneously.

Our thanks are due to Dr. William Davies for his interest in this work, for encouragement and guidance and for providing facilities to carry out these studies. We are indebted to Mr. G. E. Barton for his valuable collaboration and technical assistance, without which this work would not have been possible, and to $\mathrm{Mr}$. D. Smith for the preparation and counting of soil extracts.

\footnotetext{
${ }^{1}$ Buller, A. H. R., "Researches on Fungi", 5 (Longmans, Green and Co., London, New York and Toronto, 1933).

${ }^{2}$ Schütte, K. H., New Phytol., 55, 164 (1956).

3 Melin, E., and Nilsson, H., Physiol. Plant., 3. 88 (1950).

${ }^{4}$ Melin, E., and Nilsson, H., Svensk. Bot. Tidskr., 46, 281 (1952).

s Harley, J. L., and McCready, C. C., New Phytol., 51, 56 (1952).

- Harley, J. L., MeCready, O. C., and Brierley, J. K., New Phytol., 57, 353 (1958).

${ }^{7}$ Grossbard, Erna, and Stranks, D. R., Exp. Progr. No. 10, Grassl. Res. Inst., Hurley, 78 (1957). ${ }^{8}$ Grossbard, Erna, and Stranks, D. R., Abstr. Int. Congr. Microbiol.,
35 (1958).

- Grossbard, Erna, and Stranks, D. R., J. Gen. Microbiol., 20, 4 (1959).

${ }^{10}$ Grossbard, Erna, Nature, 182, 854 (1958).

${ }^{11}$ Middleton, L. J., Nature, 181, 1300 (1958).

${ }^{18}$ Gustafson, F. G., Amer. J. Bot., 48, 157 (1956).

${ }^{13}$ Pelc, S. R., J. App. Rad. Isotopes, 1, $172(1956)$.

${ }^{14}$ Abelson, P. H., and Aldous, Elaine, J. Bact., 60, 401 (1950). 1s Jones, G. B., Riceman, D. S., and McKenzie, J. O., Aust. J. Agric.
Res., 8, 191 (1957).
}

\title{
OBITUARIES
}

Prof. Kaj U. Linderstrøm-Lang, For.N.em.R.S.

The death of Prof. Kaj Ulrik Linderstrøm-Lang on May 25 was a great and irreplaceable loss, not only to his colleagues and friends but also the scientific community at large. The Chemical Division of the Carlsberg Laboratory in Copenhagen, which he led with such force and inspiration for twenty-one years, is perhaps unsurpassed in terms of the number of individuals who identify it as a major scientific home.

Linderstrøm-Lang was born in Frederiksberg, Coponhagen, in 1896, the son of Dr. C. F. LinderstrømLang. His education at the Danmarke tekniske Højskole led to a degree in chemical engineering in 1919, following which he became assistant to Prof. S. P. L. Sørensen at the Carlsberg Laboratory. In the environment of Sørensen's fundamental research on the physical chemistry of proteins in solution, Linderstrøm-Lang's natural talents for mathematics and laboratory experimentation lod him to conceive in 1925 his classicel paper "On the Ionisation of Proteins", which stands to-day as the fundamental theoretical treatment of protein titration curves.

During the period 1926-27 he studied in the laboratory of Prof. R. Willstätter in Munich, and there he developed his continuing interest in the chemistry and modo of action of proteolytic enzymes. Upon his return to Copenhagen he completed his earlier investigations on the electrophoretic properties of proteins and presented his doctoral dissertation in 1929.

His investigations of the nature and determination of proteolytic enzymes, developed in collaboration with the increasing flow of visiting scientists in the Laboratory, became directly applicable to the work he afterwards undertook in collaboration with Dr. Heinz Holter, who went to the Laboratory in 1930. Linderstrøm-Lang and Holter developed, over the succeeding ten years, a tremendous array of delicate and sensitive techniques for the study of the dis. tribution of a large variety of enzymes and other constituents in cells. These micro methods, now standard procedure in many laboratorios throughout the world, made possible an enormous advance in our understanding of many aspects of cellular physiology. It is characteristic of the methods that Linderstrøm-Lang developed that they were based on extremely simple but basic physical principles. Well-known examples are the Cartesian diver technique for the measurement of metabolism in single miero-sections of tissue or of individual cells, and the extremely sensitive gradient technique for the determination of the densities of minute quantities of material. A whole generation of young chemists and biologists was strongly infuenced by these methods and profited enormously by direct collaboration with Linderstrøm-Lang during this period of his scientific career.

When S. P. L. Sørensen retired in 1938, Linderstrøm-Lang was chosen as director of the Carlsberg Laboratory. Continuing along the lines begun by Sorensen, which had already made the Laboratory world-famous in protein chemistry, LinderstromLang initiated an outstanding series of studies on the internal structure of protein molecules. Using as probes such phenomena as the volume contraction occurring as a result of proteolytic cleavage of peptide bonds, he began to develop during this period his strong interest in the limited modification of proteins as one means of elucidating internal structure, and 
published many fundarnental papers on such systems as the conversion of ehymotrypsinogen to chymotrypsin and ovalbumin to plakalbumin. An example of his inexhaustible ingenuity in the development of experimental techniques was the "deuterium exchange" technique, which permitted the estimation of the relative rates at which individual hydrogen atoms within the primary, secondary and tertiary structures of a protein molecule could reach equilibration with deuterium atoms in the water in which the samples were dissolved.

Linderstrøm-Lang's scientific talents, combined. with his characteristics of warmth and perception, brought him early and frequent recognition by many organizations, both scientific and eivic. In addition to receiving numerous honorary degrees from universities throughout the world, he was a member of the Royal Swedish Academy of Sciences, the Academy of Sciences of the U.S.S.R., the Royal Society of London, the Finnish Scientific Society and the National Academy of Sciences of the United States, to mention only a few. He was, at various periods during his life, president of the Danish Academy of Tochnical Sciences, the Akademiet for de tekniske Videnskaber, and in 1958 of the International Union of Biochemistry.

The list of honours and accomplishments scattered through his career are too numerous to list in detail. Perhaps even more important than these tangibles, howevor, was the impact of his warm personality on everyone who knew him. Kaj Linderstrøm-Lang had talents in many areas of human endeavour and, had he not chosen science as his major interest, could clearly have contributed prolifically in a variety of pursuits including music, art and literature. Those who knew him will not forget his unique combination of wisdorn, humour and intellectual integrity. With his death the world lost not only a great scientist but also a great man. C. B. Antinsen, Jun.

\section{Dr. M. Copisarow}

Maurice Copisarow, who died on April 15, in his seventieth year, was a scientist of quite outstanding ability. His university education was acquired between 1909 and 1913 in the School of Chemistry at Owens College, where I knew him as a fellow student. He stayed on for postgraduate study as Dalton Research Scholar during 1914-16, working with Chaim Weizmann on "Phthalides of the Benzene, Naphthalene and Carbazole Series" (published in 1915). Afterwards, as Honorary Research Fellow (1916-19), he launched out into independent inquiries concerned mainly with reactions promoted by aluminium chloride.

During the First World War, Copisarow worked for the Ministry of Munitions and was responsible for a change in the method of washing TNT which greatly reduced the risk in handling this explosive. At the end of the War he experimented on the conversion of various explosives and also phosgene into products for which industrial uses could be found, and in these operations his eyesight suffered severe injury. Most unhappily, the damage was progressive and in a relatively short time, while still at the outset of his career, he became blind. However, by 1925 he had to his credit nineteen publications of high quality, and in that year he was awarded the D.Se. of the University of Manchester.

In his work as a chemist he could never have confined himself to narrow specialization. His mind ranged over whole fields of scientific activity, and his keenness of perception allied to his uncommonly active imagination gave rise to a versatility which is well exemplified by his generalized theory of allotropy (J. Chem. Soc., 1921) and by his work on the phenomenon of periodic precipitation, reported between 1927 and 1932 in various scientific journals. These publications illustrate admirably his ability to recognize certain apparently unrelated chemical processes and structures as forms of expression of a unifying principle and to enunciate it.

After he had lost his sight, Dr. Copisarow's scientific activities became restricted principally to the preparation of review articles and essays dealing with matters calling for theoretical consideration. His blindness seemed indeed to intensify his insight, and he extended his thinking to such subjects as the functioning of certain oxidation enzymes, the effects of radiation on enzymes and the biochemistry of virus infection. He studied these matters with the ultimate object of selecting and co-ordinating knowledge which might throw light on problems associated with the malignant growth of cells. Observations on biochemical work in the field of cancer research were published over a period of years in soveral journals, including a comprehensive review on the "History of Human Cancer", which appeared in the Edinburgh Medical Journal in 1952. Copisarow's writings on these matters were prompted by his great desire to contribute all he could to the furtherance of progress in the war on disease.

Further evidence of his feeling for the well-being of his fellow-countrymen is afforded by the interest he had in the application of appropriate scientifie knowledge to agricultural pursuits, and during the Second World War he was active in advising on methods for grassland improvement and for the reclamation of bracken-covered areas. In all, he published eighty-three scientific papers, and in recognition of special services to his country he was placed on H.M. Civil List.

Dr. Copisarow was a man dedicated to the work he had chosen, and though, in later years, he had to endure much ill-health and many worries, he remained courageous in adversity, sustained to no small degree by religious faith and by the devotion of his wife and family.

T. K. WALKMR

\section{Dr. D. S. Gracie}

VotUNTERRING in the Royal Scots at seventeen, David Smart Gracie was badly wounded on July 1, 1916, at the Somme, and spent the rest of the First World War as a prisoner in Ruhleben, an experience which marked him for life.

In the late 'twenties, after graduating at Edinburgh with a medal, and lecturing on agricultural chemistry, he went to the Colonial Service and carried out a notable "Preliminary Survey of the Soils of Kenya" before the Colonial Agricultural Service had been reconstituted.

Moving to the Egyptian Ministry of Agriculture in 1930, Gracie spent two decades investigating the fascinating problems presented by a soil which has sixty centuries of cultivation history, capped by its change to irrigation all the year round during the past hundred years. As the last survivor within that Ministry in 1949 of what had once been a strong team of some twenty British scientific ex-patriate workers, he finished with a chattering Brunsviga by collating 